\title{
Adult Stem Cell
}

National Cancer Institute

\section{Source}

National Cancer Institute. Adult Stem Cell. NCI Thesaurus. Code C43420.

Mostly multipotent undifferentiated stem cells found in a specific tissue admixed with differentiated cells. 